\title{
Endothelial Protein C Receptor gene Expression in a Female with Homozygous EPCR gene 23-bp Insertion
}

\author{
Homozigot EPCR 23-baz çifti Insersiyona Sahip Kadın Bireyde \\ Endotelyal Protein C Reseptörü Gen Ekspresyon Seviyesi
}

\author{
Afife Karabıyı, Nejat Akar \\ Ankara University, School of Medicine, Department of Pediatric Molecular Genetics, Ankara, Turkey
}

\section{To the Editor,}

Endothelial protein $C$ receptor (EPCR) is an essential component of the protein $\mathrm{C}$ (PC) anticoagulant pathway and is important for regulation of coagulation [1-3]. EPCR has a transmembrane domain, extracellular domains, and a very short cytoplasmic tail, and is primarily localized on the endothelial cells of large blood vessels. The human EPCR gene is located on chromosome 20q11.2, and has 4 exons and 3 introns $[4,5]$. EPCR has both an endothelial cell-specific transmembrane form and a soluble form that arises via metalloprotease cleavage [6].

To date, several polymorphisms and mutationsincluding a 23-bp insertion-have been reported on the human EPCR gene. The EPCR gene 23-bp insertion TATCCACAGTTCCTCTGACCATC is located between intron 2 and exon 3 (nt4031), and is related to thrombotic risk and myocardial infarction [7-10]. Exons 2 and 3 encode most of the extracellular region of the EPCR gene [5]. This insertion of 23 nucleotides preceding the insertion point (nt4031) introduces a frameshift and premature stop that deletes the entire alpha 2 domain of the gene [10]. The truncated protein results in absence of the cytoplasmic tail, transmembrane domain, and part of the extracellular domain. As such, this mutation is probably a good model for an EPCR null-allele.
Homozygous null mice embryos died prior to embryonic d 10.5, and it was reported that EPCR is essential for normal embryonic development and plays a key role in preventing thrombosis at the maternal-embryonic interface $[11,12]$. The homozygous state of EPCR gene 23-bp insertion is very rare, and we only reported it once before in a 8-month-old boy with sepsis [13].

Herein we report a 25-year-old female with homozygous 23-bp insertion of the EPCR gene. The patient had experienced abortus twice, and then gave birth following antiplatelet (aspirin) therapy. She was referred for evaluation of thrombotic risk factors to us. The family history was negative for thrombotic disease. Informed consent was provided by the patient. Her DNA was examined for factor V 1691 and prothrombin 20210 mutations, and she carried normal alleles. Factor VIII, factor IX, protein C, antithrombin, protein S, homocysteine, and lipoprotein (a) levels were normal. Plasma sEPCR was $227 \mathrm{ng}$ $\mathrm{mL}^{-1}$ (38-132 $\mathrm{ng} \mathrm{mL} \mathrm{m}^{-1}$, which was measured via enzymelinked immunosorbent assay (ELISA) (Diagnostica Stago Asserachrom sEPCR, Asnieres-France). EPCR gene exon 3 amplification was performed using primers 5'-ACACCTGGCACCCTCTCT-3' and 5'CATCCTTCAGGTCCATCC-3' at an annealing temperature of $58^{\circ} \mathrm{C}$. To detect the 23-bp insertion the PCR product was electrophoresed in 3\% agarose gel and stained with ethidium bromide. The patient

Address for Correspondence: Afife KARABIYIK, M.D.,

Suadiye Cad. 38/3 06190 Yenimahalle, Ankara, Turkey

Phone: +90 31259563 48/115 E-mail: afifekrbyk@gmail.com

Received/Geliş tarihi : November 12, 2010

Accepted/Kabul tarihi : January 12, 2011 


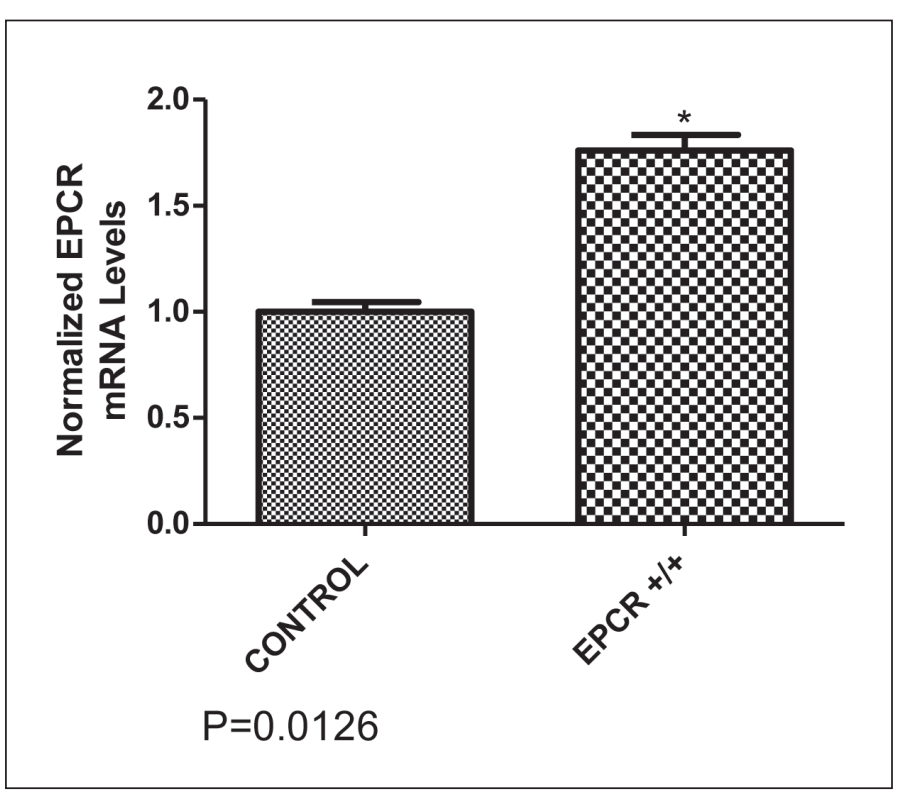

Figure 1: The EPCR mRNA level in the patient (1.7-fold higher) and control.

was homozygous for the EPCR gene 23-bp insertion mutation, and her father, mother, and child were heterozygous for the insertion.

RNA was isolated from blood samples obtained from the index case and a control, and then the level of expression of EPCR mRNA was determined (Roche Light Cycler 1.5, Basel, Switzerland), following RNA isolation and cDNA synthesis (Roche, Switzerland). Quantitative realtime (RT)-PCR was used to measure gene expression using EPCR-specific fluorescent marked UPL probes (Probe 50) and primers (EPCRF 5'-GTAGCCAAGACGCCT-3', EPCRR 5'-GATAGGGGTCGCGGA-3') (Roche, Switzerland). The glyceraldehyde-3-phosphate dehydrogenase (GAPDH) housekeeping gene was used for normalization of EPCR gene expression data. All experiments were performed twice. Statistical analysis of the results was performed using two-way ANOVA (GraphPad Prism v.5.00, GraphPad Software, San Diego, California, USA, http:// www.graphpad.com).

The patient's EPCR mRNA level was 1.7-fold higher than that of the control, as shown in the Figure 1. Because of the premature stop of the EPCR protein, which was due to the 23-bp homozygous insertion, her EPCR expression level could be higher than the control that has normal EPCR gene 23-bp mutation allele. This can be explained by the EPCR protein requirement.

Disruption of the EPCR gene in mice leads to early embryonic death [12]. The presented case is not only alive, but also gave birth to a healthy child. As the patient had abortus twice, we think that homozygous 23-bp insertion might affect the fetus negatively by causing hypercoagulability. There is a strong association between anti-EPCR autoantibodies and the risk of fetal death. High levels of IgM and IgG anti-EPCR in humans are associated with a high risk of a first episode of fetal death [14]. EPCR gene 23-bp insertion in women with fetal loss is more prevalent than in women that have given birth to $\geq 1$ healthy baby and have no history of late fetal death [11]. The data obtained in the presented case show that 23-bp homozygous mutation of the EPCR gene in humans is compatible with life. Additional research-including cases with homozygous 23-bp insertion mutations-is needed to clarify the possible effects of the insertion.

\section{Conflict of Interest Statement}

The authors of this paper have no conflicts of interest, including specific financial interests, relationships, and/ or affiliations relevant to the subject matter or materials included.

\section{References}

1. Esmon CT: The protein C pathway. Chest 2003; 124 (3 Suppl): 26-32

2. Nagai M, Terao S, Yilmaz G, Yilmaz CE, Esmon CT, Watanabe E, Granger DN: Roles of inflammation and the activated protein $C$ pathway in the brain edema associated with cerebral venous sinus thrombosis. Stroke 2010; 41 (1): 147-152

3. Taylor FB Jr, Peer GT, Lockhart MS, Ferrell G, Esmon CT: Endothelial cell protein $C$ receptor plays an important role in protein C activation in vivo. Blood 2001; 97; 1685-1688

4. Nayak RC, Sen P, Ghosh S, Gopalakrishnan R, Esmon CT, Pendurthi UR, Rao LV: Endothelial cell protein C receptor cellular localization and trafficking: Potential functional implications. Blood 2009; 114 (9): 1974-1986

5. Simmonds RE, Lane DA: Structural and functional implications of the intron / exon organization of the human endothelial cell protein $\mathrm{C} /$ activated protein $\mathrm{C}$ receptor (EPCR) gene: Comparisons with the structure of CDl / major histocompatibility complex alphal and alpha2 domains. Blood 1999; 94: 632-641

6. Kurosawa S, Stearns-Kurosawa DJ, Hidari N, Esmon CT: Identification of functional endothelial protein $C$ receptor in human plasma. J Clin Invest 1997; 100: 411-418

7. Akar N, Gökdemir R, Ozel D, Akar E: Endothelial cell protein $C$ receptor (EPCR) gene exon III, 23 bp insertion mutation in the Turkish pediatric thrombotic patients. Thromb Haemost 2002; 88 (6): 1068-1069 
8. Karabiyık A, Yilmaz E, Egin Y, Akar N: The effects of Endothelial Protein C Receptor Gene Polymorphisms on sEPCR levels in Venous Thrombotic Patients. Turk J Hematol 2010 (in press)

9. Zecchina G, Bosio S, Brusa E, Rege-Cambrin G, Camaschella C: EPCR 23 bp insertion in a patient with severe progressive arterial disease: A dominant loss of function mutant in conditions of increased APC request? Br J Haematol 2002; 119 (3): 881-882

10. Biguzzi E, Merati G, Liaw PC, Bucciarelli P, Oganesyan N, Qu D, Gu JM, Fetiveau R, Esmon CT, Manucci PM, Faioni EM: A 23 bp insertion in the endothelial protein $C$ receptor (EPCR) gene impairs EPCR function. Thromb Haemost 2001; 86: 945-948

11. Franchi F, Biguzzi E, Cetin I, Facchetti F, Radaelli T, Bozzo M, Pardi G, Faioni EM: Mutations in the thrombomodulin and endothelial protein $C$ receptor genes in women with late fetal loss. Brit J Haemat 2001; 114: 641-646
12. Gu JM, Crawley JT, Ferrell G, Zhang F, Li W, Esmon NL, Esmon CT: Disruption of the endothelial cell protein C receptor gene in mice causes placental thrombosis and early embryonic lethality. J Biol Chem 2002; 277: 43335-43343

13. Kendirli T, Ciftçi E, Ince E, Yurdakul E, Kansu A, Akar $\mathrm{N}$ : Homozygous 23-bp insertion of endothelial protein c receptor gene in a child with fatal sepsis. Pediatr Hematol Oncol 2007; 24 (3): 199-204

14. Hurtado V, Montes R, Gris JC, Bertolaccini ML, Alonso A, Martínez-González MA, Khamashta MA, Fukudome K, Lane DA, Hermida J: Autoantibodies against EPCR are found in antiphospholipid syndrome and are a risk factor for fetal death. Blood 2004; 104 (5): 1369-1374 